\title{
EPIDEMIOLOGY AND OUTCOMES OF ISCHEMIC STROKE TREATMENT IN TWO PUBLIC HOSPITALS OF CAMPOS DOS GOYTACAZES, RJ.
}

\section{EPIDEMIOLOGIA E DESFECHOS DO TRATAMENTO DE AVC ISQUÊMICO EM DOIS HOSPITAIS PÚBLICOS DE CAMPOS DOS GOYTACAZES, RJ.}

\author{
Talles Falqueto Renon', Samara Oliveira Maia', Thais Louvain de Souza, $\mathrm{PhD}^{2}{ }^{2}{ }^{3}$, Annelise Maria Wilken de \\ Abreu,PhD², Leonardo Vandesteen, $\mathrm{MD}^{2}$ \\ ${ }^{1}$ Discentes da Faculdade de Medicina de Campos, Campos dos Goytacazes, RJ, Brazil. \\ 2 Docentes da Faculdade de Medicina de Campos, Campos dos Goytacazes, RJ, Brazil. \\ ${ }^{3}$ Núcleo de Diagnóstico e Investigação Molecular, Laboratório de Biotecnologia, Universidade Estadual do \\ Norte Fluminense, Campos dos Goytacazes, RJ, Brazil.
}

ABSTRACT

Background: The main origin of functional dependence in Brazil and the world is the ischemic stroke. The early thrombolytic treatment reduces this morbidity. However, the extended in-hospital delay is the main risk factor for the suboptimal number of ischemic stroke patients who receive this treatment. Objective: To describe the management of patients admitted with ischemic stroke in two Brazilian public hospitals. Methods: This crosssectional study was carried out in two emergency units in 2016 in Campos dos Goytacazes: Hospital Ferreira Machado (HFM) and Hospital Geral de Guarus (HGG). We analyzed the prevalence of sex, age, risk factors, time of first symptoms, prescription of thrombolytic therapy and contraindications to its use. Results: None of the 130 patients with ischemic stroke received a prescription of rt-PA, even though HFM had rt-PA available throughout the period of the study. HGG does not keep this data documented. Of all, 41 patients died (31,54\%). Advancing age ( $p<$ $0.0005)$ and atrial fibrillation $3.458(\mathrm{Cl}=95 \%, 1.239$ to $10.16, p=0.0238$ ) were risks factors for the mortality in this population. Conclusions: The lack of information in medical records reveals that low staff training may be the main reason why thrombolytic therapy was not prescribed. The elevated mortality rate shows that medical care for patients admitted with ischemic stroke in our region is far from ideal. Keywords: recombinant tissue plasminogen activator, stroke, thrombolytic therapy

\section{RESUMO}

Introdução: A principal causa de dependência funcional no Brasil e no mundo é o acidente vascular isquêmico. O tratamento trombolítico precoce reduz essa morbidade. Porém, o atraso no diagnostico intra-hospitalar é um dos fatores de riscos para o número reduzido de pacientes que recebem esse tratamento. Objetivo: Descrever o manejo dos pacientes admitidos com Acidente Vascular Encefálico Isquêmico (AVEi) em dois hospitais públicos brasileiros. Métodos: Estudo transversal analítico conduzido em duas unidades de emergência em Campos dos Goytacazes: Hospital Ferreira Machado (HFM) e Hospital Geral de Guarus (HGG). Analisados sexo, idade, fatores de risco, tempo de início dos sintomas, realização de trombólise e contraindicações para sua realização. Resultados: Nenhum dos 130 pacientes com AVEi recebeu terapia trombolítica, mesmo com o rt-PA disponível no HFM durante o período estudado. $\mathrm{O}$ HGG não mantém registros sobre a medicação. No total, 41 pacientes morreram $(31,54 \%)$. Idade avançada $(p<0.0005)$ e fibrilação atrial $3.458(\mathrm{Cl}=$ $95 \%, 1.239$ to $10.16, p=0.0238$ ) foram fatores de risco para mortalidade nessa população. Conclusões: A falta de informações nos prontuários médicos revela que a falta de treinamento das equipes pode ser a maior causa da ausência de prescrição de trombolíticos. A elevada taxa de mortalidade revela que os cuidados com pacientes com AVEI em nossa região estão longe do ideal.

Palavras-chave: Acidente Vascular Cerebral; Terapia Trombolítica; Ativador de Plasminogênio Tecidual.

Corresponding author: Talles Falqueto Renon

Faculdade de Medicina de Campos, Avenida Alberto Torres, 217, Centro, Campos dos Goytacazes, RJ, Brazil. Fax number : +55 22

21012909 - e-mail: talles_renon@hotmail.com

The authors declare no conflict of interest in this study. 


\section{INTRODUCTION}

The quick identification of signs and symptoms and the correct diagnosis of ischemic stroke are essential to treat the condition. Treatment with recombinant tissue plasminogen activator (rtPA) has to start within $4.5 \mathrm{~h}$ after the first manifestation of symptoms and its has been associated with a $30 \%$ decrease in comorbidity rates. However, despite the proved efficacy and defined prescription guidelines, thrombolytic therapy is underutilized in Brazilian hospitals and in other parts of the world.

In this scenario, the present study evaluated the frequency of prescription of thrombolytic therapy in patients with clinical diagnosis of ischemic stroke admitted to the emergency unit of two public hospitals in Campos dos Goytacazes, state of Rio de Janeiro (RJ), Brazil. The main obstacles to the administration of thrombolytic therapy to these patients were also assessed. Also, the epidemiological profile of these patients, the healthcare given and the clinical outcomes of ischemic stroke were analyzed.

\section{OBJECTIVES}

To describe the management of patients admitted with ischemic stroke in two Brazilian public hospitals.

\section{METHODS}

This cross-sectional study was conducted analyzing medical records of patients diagnosed with ischemic stroke issued between January 1, 2016 and December 31, 2016 in the emergency unit of two public hospitals in Campos dos Goytacazes, RJ, Brazil (Hospital Ferreira Machado, HFM, and Hospital Geral de Guarus, HGG). Both facilities offer CT scans 24 hours a day and are equipped to give support to emergency cases. In addition to the clinical medical team, HFM has a 24-h neurosurgery service. The availability of rt-PA during the study period in these hospitals was also evaluated. This study was carried out in accordance with the recommendations of the Brazilian National Ethics Committee (national approval registry CAAE no. 56378616.5.0000.5244). The use of medical records do not need the inform consent forms.

The health authorities of Campos dos Goytacazes store all information about inpatients in the city's hospitals using a computer system called Klinikos. Medical records were searched in this system using ICDI64 as the main keyword, which denotes unspecified ischemic or hemorrhagic stroke. Others like 163.0, 163.1, 163.2, 163.3, 163.4, 163.5, 163.6, 163.8, 163.9 were also included as secondary ICDs.

The inclusion criterion was admission to emergency unit due to acute neurological deficit caused by ischemic stroke. Patients with stroke admitted to hospital due to any clinical manifestation unrelated to the disease and patients with a neurological deficit due to another pathology (especially hemorrhagic stroke confirmed by CT scan) were excluded.

The information contained in the records was transferred to specific spreadsheets and included age, sex, risk factors, time of the first symptoms, arterial blood pressure, heart rate, glycemia, prescription of thrombolytic therapy and outcome (discharge, transfer to another hospital or death).

The statistical analysis of data was conducted using the unpaired Student's t-test or Fisher's exact test in the GraphPad Prism software (GraphPad Software Inc., San Diego, CA, USA). The results were considered significant when $p<0.05$ ).

\section{RESULTS}

A total of 130 medical records were reviewed. Among those, 63 were from patients admitted to HFM and 67 were the ones from HGG. Most patients were women (59.2\%), and the mean age was 69 years. Also, 32 (24.6\%) patients were over 80 years old. The vast majority of patients (84.6\%) had hypertension, which is the most important risk factor for ischemic stroke. Diabetes mellitus was diagnosed in 49 (37.7\%) patients, while previous ischemic stroke was listed in the records of 33 (25.4\%) patients. Mortality of patients during hospitalization was $31.5 \%$ (41 patients). Half the patients were discharged, and 19 (14.6\%) were transferred to another hospital. Additionally, advanced age and atrial fibrillation were risks factors for the mortality by an acute ischemic stroke in this population (Table 1). There is no statistically significant association between diabetes, hypertension, and previous ischemic stroke with mortality in this study.

Time of first symptoms was informed in only 32 (24.6\%) of the 130 records analyzed. Of these, only ten patients got at the hospital within less than $4.5 \mathrm{~h}$ after the manifestation of first symptoms. None of the patients underwent thrombolytic therapy. No record contained any information that could be used 
Table 1. Sociodemography and risk factors p revalence of patients with ischemic stroke

\begin{tabular}{|c|c|c|c|c|}
\hline & Death & Survival & OR $(95 \% \mathrm{CI})$ & $P$ Value \\
\hline \multicolumn{5}{|l|}{ Sex } \\
\hline Female & $20 \quad(26.30 \%)$ & $(73.7 \%)$ & & \\
\hline Male & $20(37.7 \%)$ & $33(62.3 \%)$ & & \\
\hline Age, Mean \pm SD & $75.50 \pm 11.03$ & $66.16 \pm 14.65$ & & 0,0005 \\
\hline Atrial fibrillation & $10(24.4 \%)$ & $7(8 \%)$ & $3,548(1.239-10.16)$ & 0,0238 \\
\hline Diabetes & $14(58.5 \%)$ & $35(39.8 \%)$ & $(0.3621-$ & 0,5656 \\
\hline & & & $1.703)$ & \\
\hline Hypertension & $37(90.2 \%)$ & $73(87.5 \%)$ & $1,901(0.5887-6.136)$ & 0,4238 \\
\hline Previous ischemic & $12(29.3 \%)$ & $21(23.9 \%)$ & $(0.5742-$ & 0,5225 \\
\hline stroke & & & $3.035)$ & \\
\hline Overall thrombolysis & 0 & 0 & & \\
\hline
\end{tabular}

to explain why thrombolytic therapy was not given, even those ten patients who reached an emergency unit within less than $4.5 \mathrm{~h}$ after the manifestation of first symptoms.

The data obtained directly from HFM showed that rtPA was available throughout the year of 2016 to the hospital's patients. Until now, HGG does not keep a historical record of the availability and prescription of this pharmaceutical drug in the institution.

\section{DISCUSSION}

It has been shown that rt-PA revolutionized the management of acute ischemic stroke, becoming the standard therapy to treat the disease all over the world. Despite that, rt-PA is remarkably underutilized for this purpose. A study published in 2011 by the American Heart Association estimated that thrombolytic agents are included in protocols to treat between $3.4 \%$ and $5.2 \%$ of all cases of ischemic stroke in the USA. In Brazil, the prevalence of use of rt-PA in a private hospital ten years ago was $2.7 \%$. The present study showed that no patient admitted with symptoms of ischemic stroke received thrombolytic therapy, even though some patients were admitted during their therapeutic windows or with a previous episode of this disease. It reveals that rt-PA is not routinely prescribed to treat ischemic stroke, despite the well-founded relevant studies published around the world and guidelines issued by Brazilian health authorities .

Therapy with rt-PA allowed reducing hospitalization times, decreasing motor rehabilitation and functional disability costs at the same time that it improved quality of life, survival rates and the chances of stroke patients get back to work. In other words, despite the high costs of rt-PA, the favorable cost-benefit ratio indicates its use to treat ischemic stroke.

The screening coverage of stroke and time of first symptoms is essential to the decision-making process to prescribe rt-PA to a patient. The absence of time of first symptoms in medical records in the present study is alarming. The first medical care for patients with ischemic stroke does not pay attention to data that are essential in the screening of patients who may require a prescription of rt-PA.

An intervention study or strategies to reduce door-to-needle time should be carried out. However, the poor staff training and the modest efforts of hospital management teams to clarify the need to prescribe rt-PA may be the main reasons to explain why the treatment is not given. Another reason may be the unsuitable infrastructure in those emergency units since ischemic stroke patients require continuous monitoring after treatment.

The mortality rate in emergency units in Campos dos Goytacazes, RJ, is higher than the values observed in hospitals in developed countries and it is quite distinct from the figures recorded in private 
hospitals in this country. The mortality of patients with ischemic stroke described in the literature varied considerably between countries and the period that the study was carried out. The lowest mortality rate observed in Brazil was 5\%.

For the first time in those emergency units, a study for characterization of the patients admitted with ischemic stroke was performed. This study showed the persistent operational challenges that lead to underutilization of thrombolytic agents. Efforts should be made on the emergency units to sensitize all professionals involved and improve the service structure.

\section{CONCLUSION}

The underutilization of rt-PA in that two emergence units represents the reality of many public hospitals in Brazil. Unfortunately, this scenery results in elevated mortality rate showed for patients admitted with ischemic stroke and directly impact the quality of life of these patients.

\section{ACKNOWLEDGMENTS}

The authors thank the staff at the Hospital Ferreira Machado and Hospital Geral de Guarus for the assistance in collecting medical records.

\section{REFERENCES}

1. National Institute of Neurological D, Stroke rt PASSG. Tissue plasminogen activator for acute ischemic stroke. N Engl J Med. 1995;333(24):1581-7.

2. Conforto AB, Paulo RB, Patroclo CB, Pereira SL, Miyahara Hde S, Fonseca CB, et al. Stroke management in a university hospital in the largest South American city. Arq Neuropsiquiatr. 2008;66(2B):308-11.

3. Adeoye $\mathrm{O}$, Hornung $\mathrm{R}$, Khatri $\mathrm{P}$, Kleindorfer $\mathrm{D}$. Recombinant tissue-type plasminogen activator use for ischemic stroke in the United States: a doubling of treatment rates over the course of 5 years. Stroke. 2011;42(7):1952-5.

4. Katzan IL, Hammer MD, Hixson ED, Furlan AJ, Abou-Chebl A, Nadzam DM, et al. Utilization of intravenous tissue plasminogen activator for acute ischemic stroke. Arch Neurol. 2004;61(3):346-50.

5. Fonseca LHO, Rosa MLG, Silva AC, Maciel RM, Volschan A, Mesquita ET. Analysis of barriers to the use of thrombolytics in ischemic stroke in a private hospital in Rio de Janeiro, Brazil. Cad Saúde Pública. 2013;29(12):2487-96.

6. Tsivgoulis G, Alexandrov AV. Timeframe for thrombolysis in acute ischaemic stroke. Lancet. 2008;372(9646):1275-6. 7. Oliveira-Filho J, Martins SC, Pontes-Neto OM, Longo A, Evaristo EF, Carvalho JJ, et al. Guidelines for acute ischemic stroke treatment: part I. Arq Neuropsiquiatr. 2012;70(8):621-9.

8. Hill MD, Buchan AM, Canadian Alteplase for Stroke Effectiveness Study I. Thrombolysis for acute ischemic stroke: results of the Canadian Alteplase for Stroke Effectiveness Study. CMAJ. 2005;172(10):1307-12.

9. Fagan SC, Morgenstern LB, Petitta A, Ward RE, Tilley BC, Marler JR, et al. Cost-effectiveness of tissue plasminogen activator for acute ischemic stroke. NINDS rt-PA Stroke Study Group. Neurology. 1998;50(4):883-90.

10. Haesebaert J, Nighoghossian N, Mercier C, Termoz A, Porthault S, Derex L, et al. Improving Access to Thrombolysis and Inhospital Management Times in Ischemic Stroke: A Stepped-Wedge Randomized Trial. Stroke. 2018;49(2):405-11. 11. Lindsberg PJ, Happola O, Kallela M, Valanne L, Kuisma M, Kaste M. Door to thrombolysis: ER reorganization and reduced delays to acute stroke treatment. Neurology. 2006;67(2):334-6.

12. Feigin VL, Lawes CM, Bennett DA, Barker-Collo SL, Parag V. Worldwide stroke incidence and early case fatality reported in 56 population-based studies: a systematic review. Lancet Neurol. 2009;8(4):355-69.

13. Mourao AM, Vicente ACC, Chaves TS, Sant Anna SV, Meira FC, Xavier RMB, et al. Perfil dos pacientes com diagnóstico de AVC atendidos em um hospital de minas gerais credenciado na linha de cuidados. Rev Bras Neurol. 2017;53(4):12-6. 